\title{
Nubica Onomastica Miscellanea I Notes on and Corrections to Personal Names Found in Inscriptions from Faras
}

\author{
GrZEgORZ OCHALA
}

\begin{abstract}
This paper offers corrections and new readings to names found in eleven inscriptions originating from Faras. Inscriptions were discovered at different periods, ranging from the visit of Karl Richard Lepsius in 1844 to the rescue excavation by the Polish archaeological mission of Kazimierz Michałowski in 1961-1964. The material covers different types of sources (epitaphs, visitors’ inscriptions, subscriptions, and an owner's inscription) in three languages (Greek, Coptic, and Old Nubian) and spans roughly the whole Christian period in Nubia, from the seventh to the fourteenth or even fifteenth centuries. The corrections include both 'cosmetic' improvements in reading (e.g. from the form anane to $\mathbf{N} \mathrm{N} N \mathrm{H}$ ) as well as identification of ghost-names (e.g. the highly unusual name Theoria, which is in fact a misreading of Theophil).
\end{abstract}

Keywords: Christian Nubia, Faras, Greek, Coptic, Old Nubian epigraphy, onomastics, ghost-names

Grzegorz Ochała, Institute of Archaeology, University of Warsaw, Warsaw; g.ochala@uw.edu.pl; (D) 0000-0002-1935-0508

Christian Nubian onomastics is a rich and so far surprisingly unresearched trove of information on the society of the Middle Nile Valley between the sixth and fifteenth centuries. In the research project entitled 'What's in a name?' A study on the onomastics of Christian Nubia, I undertook the task of exploring this material from both the formal and sociocultural perspectives. The present article is the first in a series of papers that will present the outcomes of one of the most important elements of this project, namely the verification of all instances of anthroponyms found in the corpus of Nubian written sources. The purpose was to establish the original forms of names as accurately as possible, correct the readings, eliminate words falsely identified as names (so-called ghost-names), and - vice versa - single out names falsely interpreted as other types of words. The task proved to be difficult or even impossible in some cases due to two major factors: the state of preservation of texts, on the one hand, and the state of their publication on the other. The former, 
obviously, in many cases makes it impossible to arrive at a one hundred per cent certain reading. Moreover, some more difficult readings heavily rely on apparent similarities of surviving traces of letters with known name-forms, which, of course, may not be the case at all. Also, in the case of lacunary names, one can never be sure whether one variant of the name should be reconstructed or the other, an especially sensitive question given frequent vocalic interchanges, sometimes quite unpredictable, and a number of abbreviated nameforms. Finally, the lion's share of the repertoire of Nubian names is made up by names of local Nubian stock, the great majority of which are attested once or a handful of times at most, which obviously prevents any attempts at reconstruction.

The latter question, that is shortcomings in the publication of Nubian textual material, is equally problematic, but even more frustrating. The question of accessibility of material, scattered throughout a huge amount of bigger and smaller articles and notes, excavation reports, and even memoirs of nineteenth-century travellers, has at least partly been solved by the on-line Database of Medieval Nubian Texts (DBMNT), ${ }^{1}$ which aims at collecting the metadata (for the time being) on every single instance of written expression in Christian Nubia. Nevertheless, however comprehensive the DBMNT struggles to be, it is based on what has been published and its shortcomings are in fact the shortcomings of the publications to which it refers. For the verification of Nubian personal names, or of any kind of information provided by the sources for that matter, it is crucial to have at one's disposal illustrations, most ideally quality photographs. These, unfortunately, are as a rule lacking in the majority of older publications ${ }^{2}$ and, even more surprisingly, in some more recent ones. ${ }^{3}$ Drawings, which sometimes accompany publications of Nubian texts, no matter how detailed, are but interpretations of what the drawer thought he could see and may therefore be not only unhelpful but even deceiving, presenting faulty or non-existent forms as completely certain readings. ${ }^{4}$ Yet, even in such difficult cases, it was not so infrequently possible to achieve satisfactory results. Thus, despite all these obstacles, the verification of Nubian onomastic material has turned out to be quite successful. For 1,911 texts recorded in the DBMNT as containing personal names, ${ }^{5}$ smaller or bigger corrections could be introduced in nearly 100 of them pertaining to some 250 individual attestations of names.

I present here onomastic corrections to epigraphic sources originating from Faras. The material covers different types of sources (epitaphs, visitor's inscriptions, subscriptions,

${ }^{1}$ The abbreviation DBMNT used throughout this paper denotes a catalogue number of a text in the database.

${ }^{2}$ One of the most relevant older examples is the publication of funerary stelae from the cemetery of Sakinya: for 315 pieces, only 77 have been published with an illustration, among which 66 with photos and/or drawings and 11 with drawings only: Monneret de Villard 1933: Pls I-VIII; Mina 1942: Pls I-XVI; Pernigotti 1975: Pls VII-XVI; Kamel, Girgis 1987: Pl. XLV, Fig. 31; Brunsch 1991: Pl. 20; 1995: Pls on pp. 79-83, 85-87.

${ }^{3}$ Here William Adams's final reports of excavations in Meinarti and Kulubnarti are especially frustrating, as they reproduce tiny photos in a poor-quality print (e.g. Adams 1994; 2002).

${ }^{4}$ There are many other methodological problems that had to be dealt with during the work on the project; they will be presented in detail in my forthcoming monograph on Christian Nubian naming practices.

${ }^{5}$ The figure is taken from the off-line version of the DBMNT (state for July 2018), which currently contains 4,138 records, as compared with 2,942 in the on-line database; the DBMNT on-line will be updated together with launching the Database of Medieval Nubian Names planned for 2020. 
and an owner's inscription) in three languages (Greek, Coptic, and Old Nubian) and spans roughly the whole Christian period in Nubia, from the seventh to the fourteenth or even fifteenth centuries. ${ }^{6}$ Some of the new readings presented here are in fact quite obvious or even banal and must have been noticed by other scholars too (and indeed they were, as in no. 2 below), but none of them has so far appeared in print.

The material presented here is organised typologically, starting from funerary stelae and ending with an owner's inscription. Where possible, the discussion is supported by relevant illustrations. Note that the corrections are made with reference to the latest edition of the text, but they always take into account previous publications. For the readers' convenience, a table at the end of the paper (Tab. 1) indexes all corrections discussed here, with an indication of the Nubia Onomastica Miscellanea number introduced below (NOM I nos 1-10).

For rendering proper names standing outside their actual linguistic context, I use the Coptic font throughout the article, as it reflects in the best possible way the actual graphic form of the word. This should by no means be treated as a marker of the 'language' or genealogy of the name. On the other hand, whenever the names are quoted with the surrounding context, the font is adjusted accordingly: Coptic font for Coptic and Nubian linguistic contexts, Greek font for Greek context.

\section{EPITAPH OF IESOUSINTA(?) [DBMNT 488]}

This Greek funerary stela dated to the ninth-tenth century was found by Karl Richard Lepsius somewhere in Faras during his journey through Nubia in 1844. It was brought by him to Berlin along with other objects he collected on the way. It was once stored in the Ägyptisches Museum (inv. no. 1486), but has been lost since World War II. ${ }^{7}$ Just as with the rest of his finds, Lepsius published only the drawing of the stela. ${ }^{8}$ On the basis of this drawing, Ernest Curtius and Adolf Kirchhof prepared the first edition of the epitaph in the Corpus inscriptionum Graecarum published in the years 1856-1859 (CIG IV 9119). In subsequent years, the text was republished four times, by Eugène Revillout in 1885, Gustave Lefebvre in 1907, Hermann Junker in 1925, ${ }^{9}$ and Friedrich Bilabel and Emil Kießling in 1955 (SB V 8726).

Roughly half of the text is lacking on the right, but at first sight, the name of the person commemorated in this epitaph is completely preserved in line 6. On the basis of the drawing published by Lepsius and the photo included in Junker’s article (Fig. 1), the fragment can

\footnotetext{
6 The remaining corrections are discussed in four other articles to be published elsewhere: one devoted to funerary inscriptions in Greek and Coptic from Sakinya (Ochała 2017), one to inscriptional and documentary sources in Greek, Coptic, and Old Nubian from other Nubian sites (Ochała 2018), and at least two to Old Nubian documents from Qasr Ibrim, one of which has been accepted for printing (Ochała forthcoming) and another, a reedition of two lists of names, is in preparation.

${ }^{7} \mathrm{LD} \mathrm{V}$ (text), 182, gives inv. no. 1480. Information on the correct inventory number and the fate of the stone I owe to Cäcilia Fluck (Skulpturensammlung und Museum für Byzantinische Kunst, Berlin).

${ }^{8}$ LD VI (plates), XII, Pl. 99, Gr. 537.

${ }^{9}$ Revillout 1885: 30-31, no. 43; Lefebvre 1907: no. 634; Junker 1925: 117-120, Pl. after p. 112, Fig. on p. 118.
} 


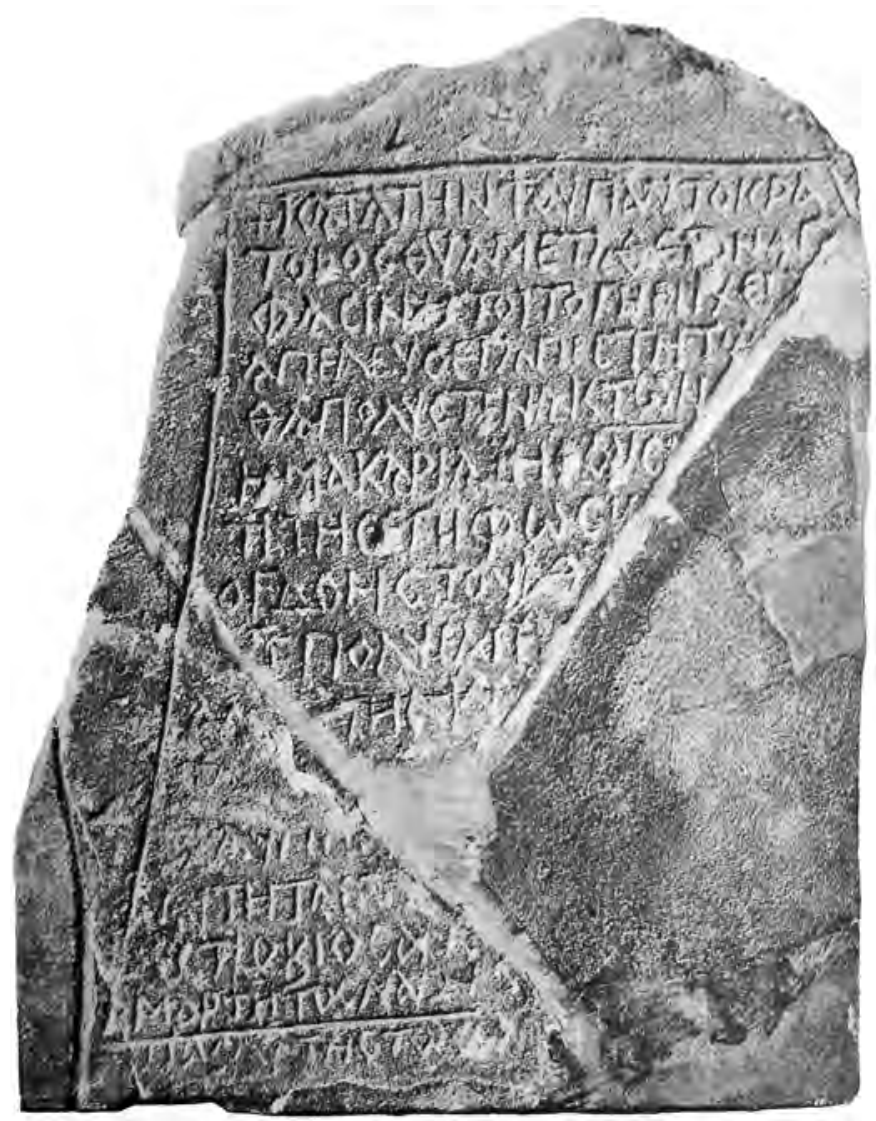

a

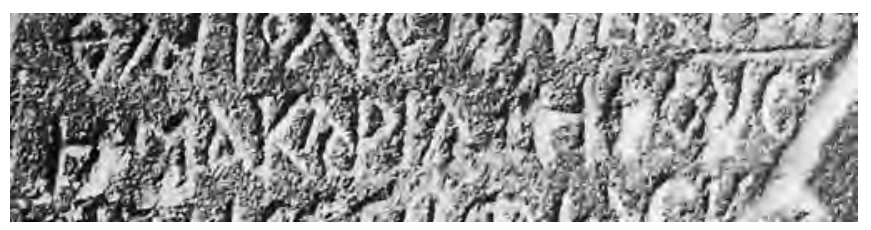

1a. Epitaph of Iesousinta(?); b. detail of inscription (Junker 1925: Pl. after p. 112).

b

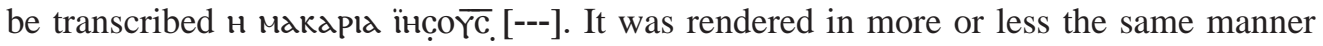

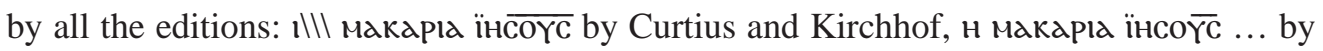

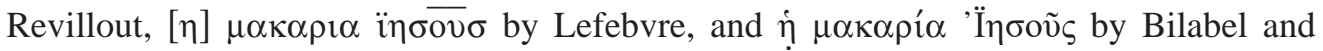
Kießling. ${ }^{10}$ While Revillout as well as Bilabel and Kießling treat it as a complete anthroponym, 'the blessed (f.) Iesous', Lefebvre notes in the apparatus that the supralinear stroke above the final letters must signal an abbreviation, which, however, he refrains to resolve.

${ }^{10}$ For unknown reasons, their re-edition takes as its model Lefebvre’s earlier publication, ignoring the work of Junker. 
In his 1925 article, Junker goes a step (or even two steps) further, as he proposes a complete reconstruction of the missing text, including the name-date lemma. For this

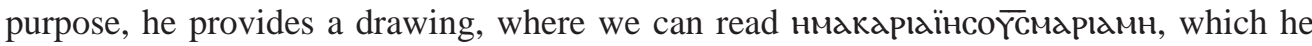

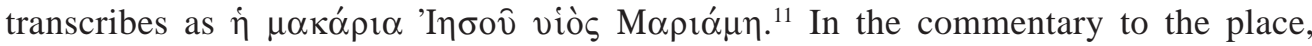
he explains that he takes $\overline{\gamma c}$ to be the usual abbreviation for viós, 'son', and the fragment of the letter visible after the sigma to belong to a mu. He justifies his interpretation and reconstruction with another Nubian epitaph commemorating the death of a certain Iesou son of Mariami. ${ }^{12}$ In both cases, he argues, the deceased are to be considered women ${ }^{13}$ and the phrase is to be understood not as a name with a metronymic, but as a sentence functioning as an anthroponym, that is 'Jesus is the son of Mary', and that because of the mere juxtaposition of the two biblical names. ${ }^{14}$

Attractive as it may appear, Junker's reconstruction of the second part of the name and his argumentation are not quite convincing. It seems oversophisticated and based on not very strong arguments. The disagreement of the gender between the supposed two attestations of this complex name is puzzling: in the other epitaph the commemorated deceased is surely a $\operatorname{man}^{15}$ and here we are doubtlessly dealing with a woman. Taking this into account, another reconstruction can be proposed. As a matter of fact, $\overline{\gamma c}$ does not have to be the abbreviation for viós, but rather an integral element of the name. This is all the more possible since the former case assumes, as noted by Junker, the presence of a haplography: $\ddot{\text { iнсо }}<\gamma>\overline{\gamma \mathrm{c}}$ мдргдмн. Instead of being the mark of an abbreviation, the supralinear stroke could have the typical syllabic function of the native Nubian language representing the vowel /i/. Of course, such a stroke does not make any sense above the upsilon + sigma, but it may have been shifted to the left from its original position above the cluster of sigma + a consonant, which we appear to have here and which would be a perfect position for it. According to Junker, the letter after the sigma consists of a vertical stroke with traces of a diagonal line protruding to the bottom right from its top. He took it to be a mu, but it could as well be a nu. Provided the above reasoning is correct, we would have a name starting with ïrcorcị--, a very good beginning for a composite Nubian name. In fact, two

11 Note that his transcript is not an edition in the modern sense, as it presents the text in normalised orthography and without any editorial signs.

12 The latest edition in Łajtar, Twardecki 2003: no. 109 (probably Faras, AD 1173 [DBMNT 73]).

13 He acknowledges (Junker 1925: n. 2 on p. 119) the presence of the masculine article $\tau$ óv before the name of the deceased Iesou in Łajtar, Twardecki 2003: no. 109, line 7, but he claims that this can hardly be a proof of the gender of the person because of the generally bad Greek of the epitaph.

14 Junker follows the argumentation of Weißbrodt 1905-1906: 20-21. Adam Łajtar, in Łajtar, Twardecki 2003: no. 109, ad line 8, agrees with this reasoning but he adds yet another argument, namely that metronymics were never used in Christian Nubia. However, a number of examples contradicting the latter assumptions can be cited: e.g. Mariami daughter of Marianta (Faras, eleventh century; Jakobielski 1974: 298-299, no. 33b [DBMNT 1853]); Menanta daughter of Mariham (northern Nubia, ninth century; P. Lond. Copt. 449 [DBMNT 630]); Maria daughter of Sousanna (northern Nubia, eighth-ninth century; P. Lond. Copt. 452 [DBMNT 632]), or Maria daughter of Thekla (northern Nubia, AD 696-710; P. Lond. Copt. 447 [DBMNT 628]). Of course, in all these cases the gender of the parent was not otherwise indicated, but we have no reason to doubt that such names as Mariami, Mariham, Sousanna, or Thekla were exclusively female.

15 The newest edition in Łajtar, Twardecki 2003: no. 109 does not leave any doubts for this. 


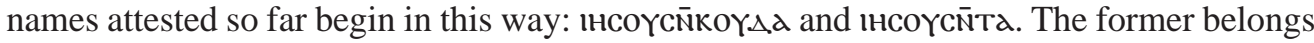
to a broader group of Nubian names constructed with the element -koץ $\lambda d$, 'servant', which appear to belong exclusively to men. ${ }^{16}$ It can therefore be excluded here. The latter, in turn, has been confirmed as a female name. ${ }^{17}$ It represents an apparently female class of Nubianised foreign names consisting of a Graeco-Biblical name plus the ending -nta. ${ }^{18}$ Thus, if the above assumption is right, the name of the deceased should be reconstructed

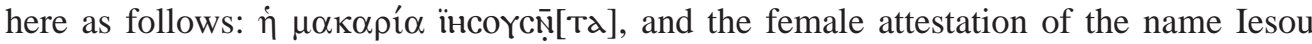
should be struck out from the extant lists of names.

\section{EPITAPH OF THEOPHIL [DBMNT 1592]}

This Coptic stela was discovered by Francis Llewelyn Griffith in the so-called Church in the Mastaba Field at Faras excavated in 1909-1910 in the framework of the Oxford Expedition to Nubia. It can only be very broadly dated to the seventh-twelfth centuries. The epitaph was published by Griffith himself in the form of a translation accompanied by a drawing (Fig. 2c).$^{19}$ It is presently kept in the British Museum (inv. no. EA160; Fig. 2a).

In Griffith's translation, the name of the deceased is rendered as 'our brother Theoria the deacon'. Griffith found such a name strange, especially as given to a man, but he concluded that the occurrence of such a name must be connected with the lack of grammatical gender in the Nubian language. Stefan Jakobielski, who offered the first transcription of the epitaph, followed Griffith's reading and transcribed nєncon өєopid. ${ }^{20}$

Such a name is indeed strange and, moreover, unattested elsewhere in either Nubia or Egypt. In a personal communication, Renate Dekker has recently proposed that the name could be Theophil instead of Theoria. ${ }^{21}$ Her proposition, based solely on Griffith's drawing,

16 Satzinger 1992.

17 In the epitaph of the woman Isousinta from Ghazali (latest edition in Tibiletti Bruno 1964: no. 33 [DBMNT 996]); until recently the name of the deceased was transcribed as coxcinTd, but my study of the archival photo of the stela shows without a shadow of a doubt that the correct reading is icoycinta. I am currently preparing the publication of all funerary inscriptions from the monastery at Ghazali. In the remaining four cases, the gender of persons bearing this name is not explicitly stated: unidentified son of Iesousinta in a visitor's graffito from Sabagura (Donadoni 1962: 93 [no. a], Pl. 28/2 [DBMNT 994]), Marteri daughter of Iesousinta in a dedicatory inscription from Faras (Kubińska 1976a: 451-455, Pl. 8 [DBMNT 1854]), Mari and Mariam daughters of Iesousinta, thus most probably sisters, in two epitaphs from Sakinya (Mari: Mina 1942: no. 314 [DBMNT 392]; Mariam: Mina 1942: no. 317 [DBMNT 395]).

18 Apart from Iesousinta, this class includes such names as Marianta, Menanta, Petrosinta, and Michenta. The ending -nta should most probably be analysed as the Old Nubian genitive - $\mathrm{N}$ plus the Old Nubian noun Td-, 'path, street'. The meaning of these names would thus be '(the one who is treading) the path of Jesus/Mary/ Menas/Peter/Michael'.

19 Griffith 1927: 62, 104-105, Pl. 42/1.

20 Jakobielski 1972: 170-171.

${ }^{21}$ Based on Dekker's suggestion, in a revised version of his 1999 article republished in 2018, Jacques van der Vliet writes: A characteristic example of this formula, in the epitaph of a Deacon Theophilus, has actually been found in Faras itself and strongly suggests that the so-called Church on the Mastaba Field had been dedicated to Saint Isidore (Van der Vliet 2018: 332; the original version [Van der Vliet 1999] has 'Deacon Theoria' on p. 93). He, however, does not discuss this correction. 

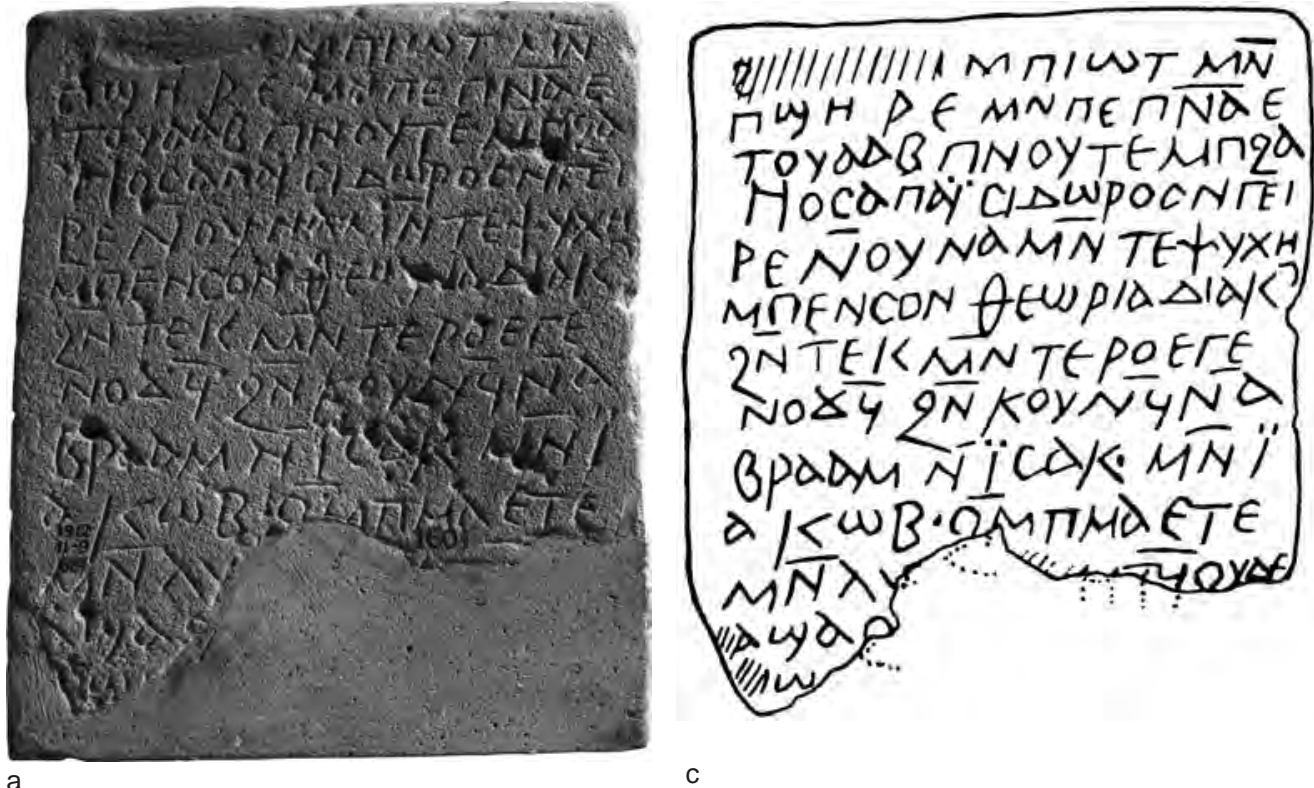

a

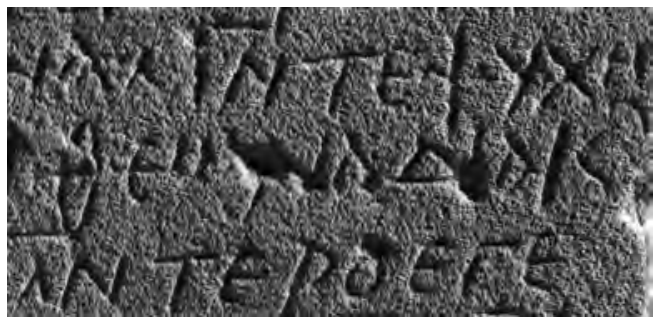

2. Epitaph of Theophil: a. photograph; b. detail of the inscription; c. drawing (a-b. (C) The Trustees of the British Museum; c. Griffith 1927: Pl. 42/1).

b

can now be confirmed thanks to a photograph made recently available at the web-page of the British Museum. At the first sight, the last letter of the name indeed looks like an alpha, but upon a closer inspection what Griffith took to be the lower stroke of the loop seems to be just a damage to the stone, and should thus rather be considered a lambda (Fig. 2b). The middle part of the word is more difficult to correct, as there is a hole in the place where Griffith's putative rho should be. In fact, only the lower part of the vertical stroke of the letter survives. What precedes it, however, should be an omikron instead of Griffith's omega, as the right-hand part of this putative omega is practically invisible. If, thus, we accept both corrections, we can safely assume that the damaged letter in the middle of the word is in fact a phi, not a rho. Hence, өєoфi $\lambda$ should be the new reading and Theoria should be considered a ghost-name. 


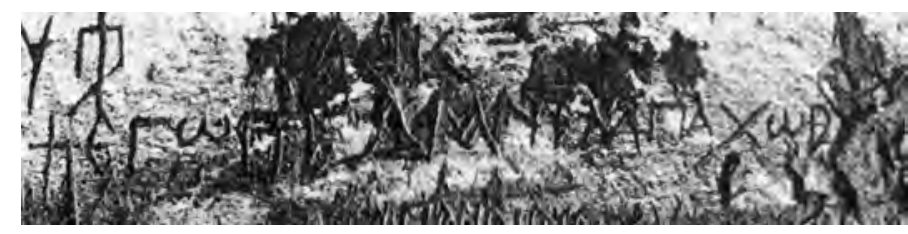

a b
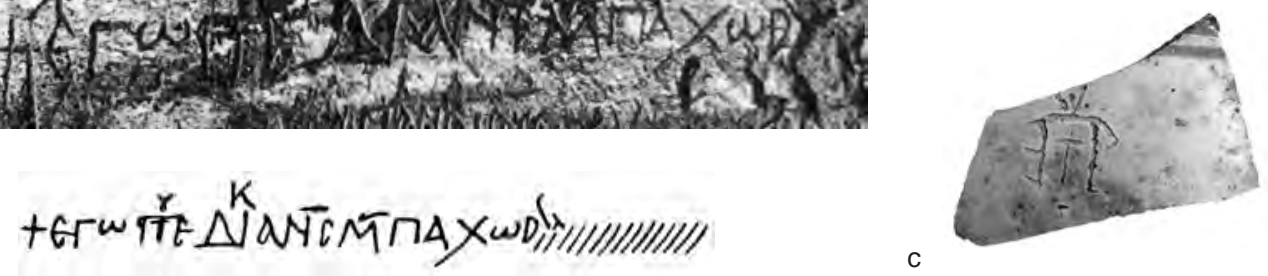

3a-b. Inscription of deacon Petrou (photograph and drawing); c. monogram of Petrou on a sherd found in Ghazali, inv. no. A.050 (a-b. Griffith 1927: Pls 64/2, 73/19; c. Phot. G. Ochała; courtesy of PCMA UW).

\section{INSCRIPTION OF PETROU, DEACON [DBMNT 1673]}

This is another text originating from Griffith's excavation at Faras in 1909-1910. The graffito, composed in a mixture of Greek and Coptic, belongs to a set of inscriptions left by visitors on the walls of the so-called Anchorite's Grotto on the outskirts of Faras, where a certain monk Theophilos, undoubtedly a local holy figure, lived, died, and was apparently buried. After his death, the tomb became the place of veneration, generating a significant pilgrim movement. All inscriptions left by visitors can be dated between the eighth and eleventh centuries. The texts were superficially published by Griffith in his 1927 report of excavation in the hermitage, limited to provisional translations accompanied by drawings and, in some cases, photographs. ${ }^{22}$

The inscription discussed here was incised on the south wall of the room and its translation by Griffith is as follows: 'I Petu(?) deacon of Pachoras ...'.23 Both the photo and the drawing (Fig. 3a-b) show that the name of the author was noted down as the monogram rft, which Griffith resolved as Petu (пєтоҮ in transcription). However, the loop that can be seen as protruding from the left side of the central $\pi$ is most surely yet another letter, namely a rho written in the mirror image. The monogram should therefore be resolved as пєтроҮ, a variant of the name Petros. Several other instances of this monogram are found in inscriptions on pottery from the monastery of Ghazali. In some cases, the order of the letters is reversed: the rho is on the right and the epsilon on the left (Fig. 3c) ${ }^{24}$ which leaves no doubt as to the interpretation of the present monogram.

\section{INSCRIPTION OF PETRO [DBMNT 1666]}

On the same wall of the Anchorite's Grotto, slightly to the left of the previous inscription, another person scratched his memento (Fig. 4). In Griffith's translation, the

\footnotetext{
22 Griffith 1927: 90-91, Pls 62-65, 73 and 74.

23 Griffith 1927: 91 (gr. 19), Pls 64/2, 73/19.

${ }^{24}$ All are unpublished; I am preparing the edition of this material.
} 


\section{$\triangle N O I S E$

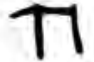

4. Inscription of Petro (Griffith 1927: Pl. 73/12).

inscription reads 'I Peti', which seems to be confirmed by the drawing, where we can easily read anok nєтı. ${ }^{25}$

While the name Peti is indeed attested in Christian Nubia, a closer look at the photograph reveals that the final letter has a small loop protruding to the right on the top and therefore seems to be rather a rho. ${ }^{26}$ No traces of letters are distinguishable after it suggesting that the text was unfinished for some reasons. Note that the northern wall of the grotto bears the inscription reading 'Petro' (DBMNT 1685), which, judging by its palaeography, especially the ligature of tau and rho, was most probably left by the same person.

\section{INSCRIPTIONS OF ANANI, CLERIC [DBMNT 1830 AND 1831]}

The next seven texts to be discussed were all discovered during the Polish excavations at Faras between 1961 and 1964 in and around the cathedral church. They were published by Stefan Jakobielski and/or Jadwiga Kubińska, the only two scholars who have so far dealt in a more comprehensive manner with the written record unearthed during the Polish work on the site. ${ }^{27}$

The first two texts in this group were found on the south wall of the narthex of the Faras cathedral (inv. nos A 4d.3 and A 4g.3). There, a certain cleric scratched his signature twice, very close to one another. In the first edition of these texts, Stefan Jakobielski proposed identical transcription for both of them: eгW aNaNe $\mathrm{K} \lambda \mathrm{H}^{28}$

One of these graffiti (inv. no. A 4g.3 [DBMNT 1831]) was subsequently republished by Jadwiga Kubińska, who repeated Jakobielski's edition, but in the Greek font: 'E $\gamma \grave{\omega}$ 'Av $\alpha v \varepsilon$ $\kappa \lambda \eta(\rho ı \kappa o ́ s) .{ }^{29}$

While andwe is otherwise unattested as a personal name or a variant thereof, a closer look at the photograph (Fig. 5) allows introducing a significant correction to the reading. It appears that in both cases the final epsilon was misread for an eta. The correct form of the name is therefore andNH. While the form as such has so far been unattested, it is phonetically equivalent to aNaNi, a variant of the biblical name Ananias found three times in two

25 Griffith 1927: 91 (gr. 12), Pls 64/2, 73/12.

${ }^{26}$ The photograph cannot be reproduced here, as the inscription is very small and the illustration would become extremely pixelated.

27 Jakobielski 1965; 1972; Kubińska 1974. Together with Adam Łajtar, we are planning to publish the corpus of wall inscriptions from Faras, including the re-edition of texts already published; for the first results of our work, see: Łajtar, Ochała 2015; 2017; and 2018.

28 Jakobielski 1972: 90, Fig. 16.

${ }^{29}$ Kubińska 1974: no. 35, Fig. 37. 


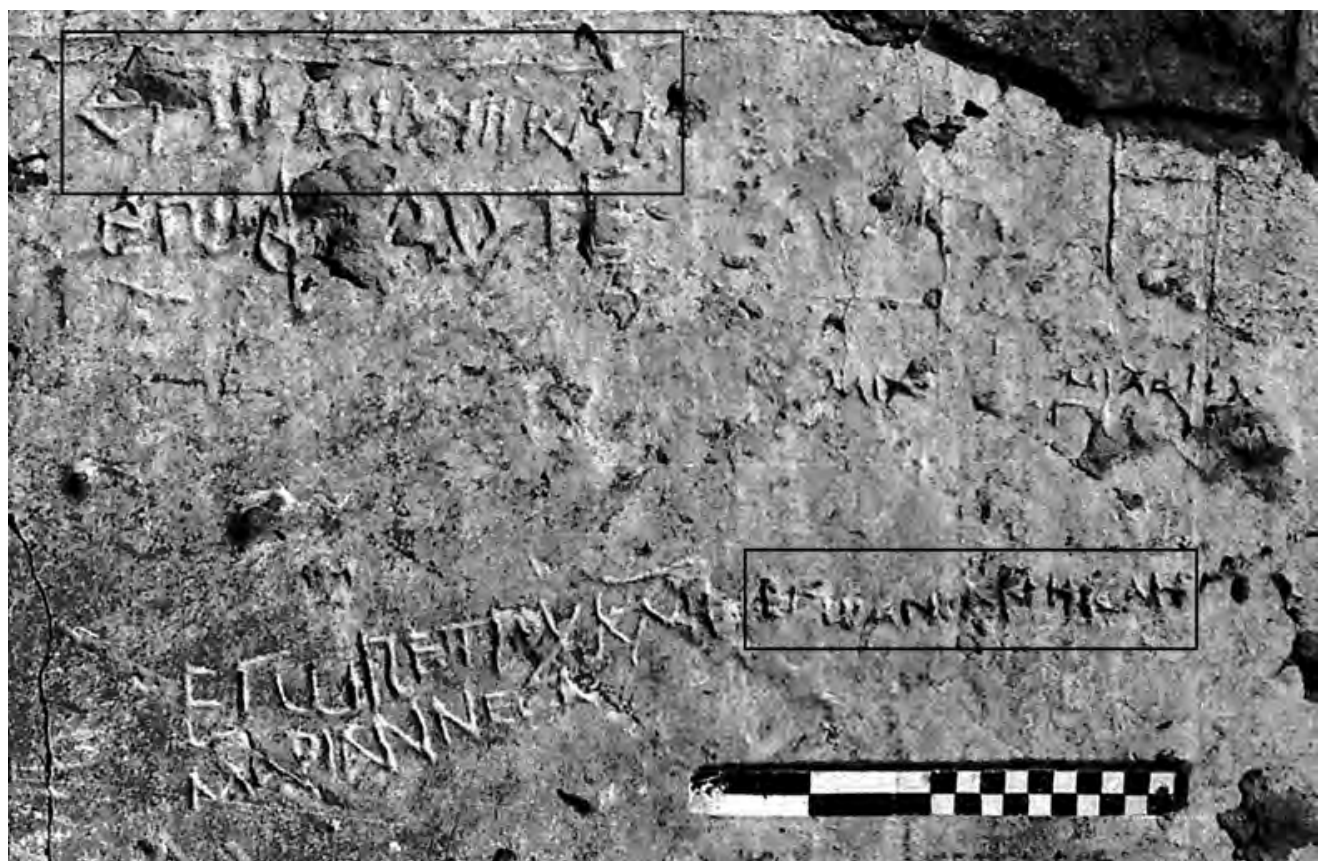

5. Inscriptions of Anani, marked with rectangles (neg. no. Fa.62/3.1460; courtesy of IKŚiO PAN / PCMA UW).

Egyptian sources: once in O. Vind. Copt. 132 (Thebes, seventh-eight century) and twice in P. KRU 119 (Djeme, eighth century). The form anawe should therefore be considered a ghost-name or a ghost-variant.

\section{INSCRIPTION OF INYITTA, CLERIC [DBMNT 1851]}

The present inscription was painted with black ink on the east side of a pilaster in the west part of the main nave of the cathedral in Faras some time in the twelfth-thirteenth century (inv. no. B 26b.3). The text has so far been published three times, twice by Stefan Jakobielski in 1972 and 1974 and once by Jadwiga Kubińska in $1974 .^{30}$ In all of these editions the name of the visitor was transcribed as if there were a lacuna in its centre: Jakobielski

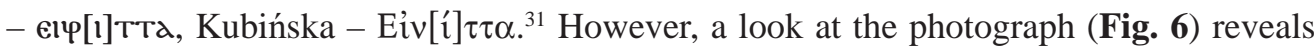
that there was no damage of the text in this place and that, moreover, there is no place for an additional letter between the $\varphi$ and the first $\mathrm{T}$. In addition, there is no iota in this place in all other attestations of the name, altogether fifteen. The reading should therefore be corrected to еІчтTd, a standard form of this name. On the basis of other attestations, we

30 Jakobielski 1972: 175, Fig. 57; 1974: 303-304, no. 43, Fig. on p. 303; Kubińska 1974: no. 38.

31 She obviously misinterpreted the Nubian letter $\varphi$ for a $\mathrm{N}$, a mistake that needs not bother us here. 
6. Inscription of Inyitta (neg. no. Fa.62/3.0869; courtesy of IKŚiO PAN / PCMA UW).
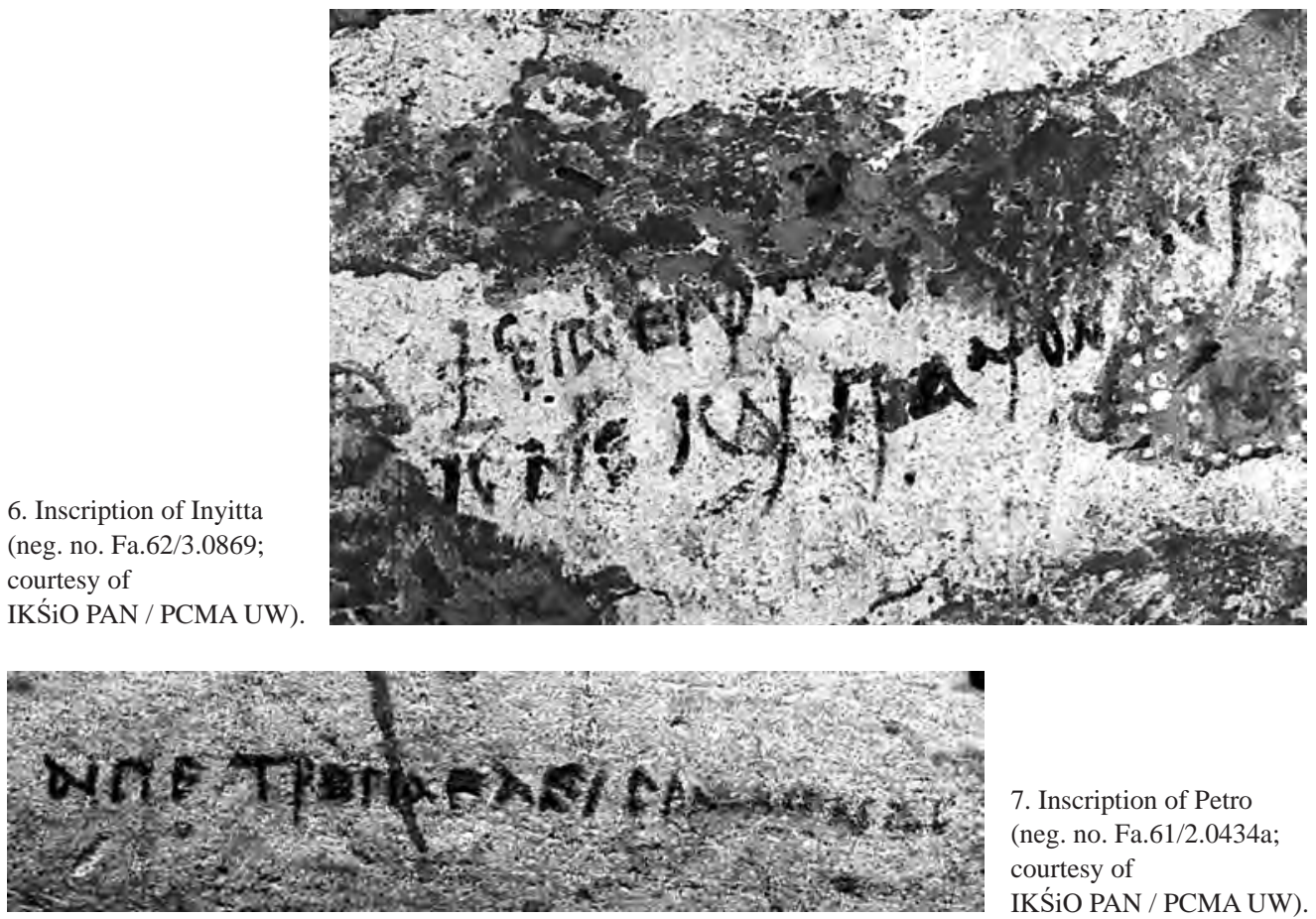

7. Inscription of Petro (neg. no. Fa.61/2.0434a; courtesy of IKŚiO PAN / PCMA UW).

can assume that there was a supralinear stroke above the first tau, indeed representing the sound /i/, but the plaster is damaged there beyond recognition.

\section{INSCRIPTION OF PETRO [DBMNT 1757]}

This text was recorded on one of the sandstone blocks found reused in the construction of the south wall of the cathedral at Faras (inv. no. S. III [C]). It belongs to a series of ink school inscriptions that appear to have been executed at one time and perhaps even by the same person (inv. nos S. III [A-I]). Among them, there are three alphabets, a set of vowels, and several other texts of an unidentified nature. ${ }^{32}$ One inscription of the last group was transcribed by Stefan Jakobielski, the first and so far the only editor of those

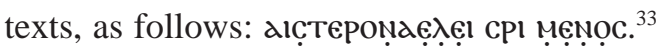

It thus seems to be a random string of letters, without any apparent order or meaning. However, a closer look at a photograph (Fig. 7) allows a correction to Jakobielski's readings and gives the inscription a proper sense. The presence of the letters al at the beginning suggests that this may be the Old Nubian personal pronoun 'I', after which

\footnotetext{
32 Jakobielski 1965: 176-178, nos 10A-I.

33 Jakobielski 1965: 178, no. 10C, Figs 48, 94-95.
} 


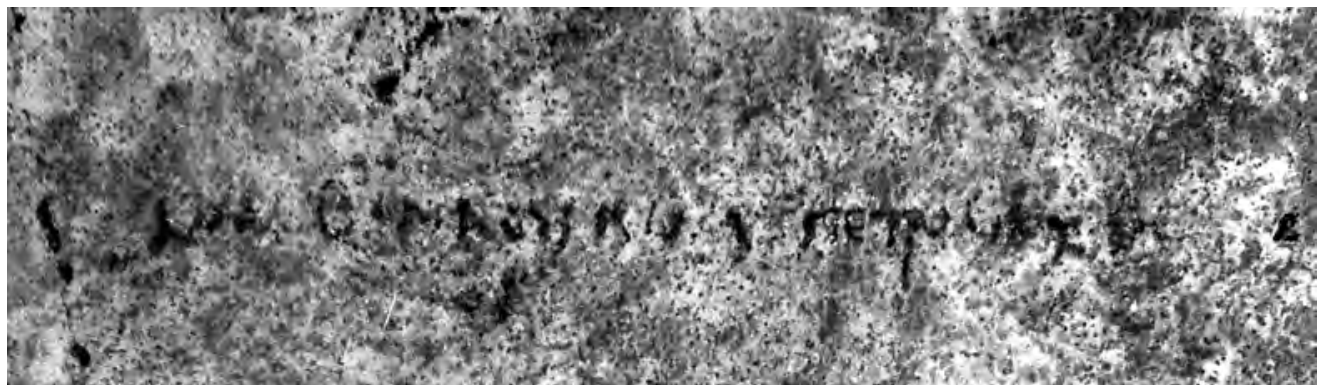

8. Inscription of Petro (neg. no. Fa.61/2.0705; courtesy of IKŚiO PAN / PCMA UW).

we normally expect a personal name. And indeed, instead of Jakobielski’s çтєpo, the inscription clearly reads пєтро. The transcription of the reminder of the text can also be

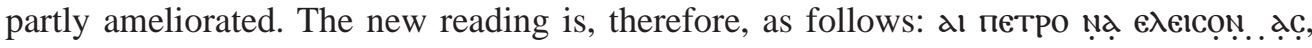
'I Petro .. (?), have mercy ...'.

The two letters after пєтро are not very clearly visible and their meaning is doubtful. They could belong to the name, producing the form пєтромฺ. If so, this would be a variant of the female name пєтроміג, but such a variant has so far been unattested. Moreover, we have no certain attestation of a woman being an author of or mentioned in a visitor's inscription in Nubia. Because of that, I prefer to treat пєтро as the name of the author, all the more so since this variant is well attested in the Nile Valley, including Faras (see, e.g. no. 4 above and no. 8 below). The final letters are also problematic. Perhaps they should be transcribed ụmạc, for 'have mercy on us'? ${ }^{34}$

If all the inscriptions on this stone block were indeed written by one hand, we can suppose that this hand belonged to Petro. The present text can therefore be seen as a subscription, by which Petro commemorated his process of education.

\section{INSCRIPTION OF PETRO [DBMNT 1786]}

Another person by the same name is mentioned in a dipinto recorded to the right of the south-western entrance to the Faras cathedral, on the west face of the outer wall (inv. no. O 304a.3). ${ }^{35}$ According to Stefan Jakobielski, the dipinto was written with the same hand as the three-line inscription located immediately below. ${ }^{36}$ They both should be dated to the eleventh-fifteenth century. Because of the occurrence in the latter text

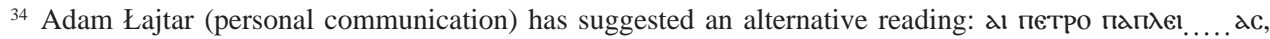

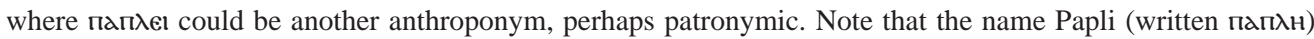
is on record in several inscriptions from the church at Sonqi Tino, not so far away from Faras (unpublished, mentioned in Donadoni 1975: 37 [DBMNT 2909-2911]; the inscriptions from Sonqi Tino are being prepared for publication by the Sonqi Tino Collaborative headed by Vincent Laisney and including, among others, myself).

35 Jakobielski 1974: 309, no. 55a + Fig.

36 Jakobielski 1974: 309, no. 55b [DBMNT 1787]. 
9. Subscription of Papi (neg. no. Fa.62/3.639; courtesy of IKŚiO PAN / PCMA UW).

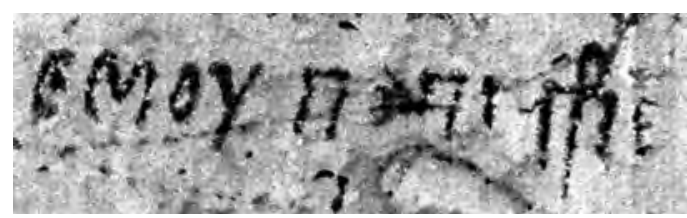

of the name Merkoure, both inscriptions can probably be linked to the representation of St Merkourios painted above them. ${ }^{37}$

Jakobielski based his edition of both texts on the original inscriptions preserved in the National Museum in Warsaw. In their present state, the texts appear to be almost completely illegible, and Jakobielski was able to transcribe only single letters in the first dipinto: $\lambda_{\text {.. a }}$ kạı [---]. However, a photograph taken at the site shows that its original state of preservation was much better (Fig. 8): what is now invisible in the lacuna appears to once have included the personal name пєтро.

Unfortunately, the rest of the text remains illegible, but assuming that the two dipinti were indeed executed by the same person and that the lower text refers to St Merkourios, it seems probable that the name Petro does not denote here a saint, but rather a living person, probably the man who commissioned the execution of the inscription or even the author himself.

\section{SUBSCRIPTION OF PAPI, PRIEST [DBMNT 2112]}

The name to be discussed here belongs most probably to the author of a long Greek inscription recorded on the northern wall of the north pastophorium in the Faras cathedral and dating to the tenth century (inv. no. G 61a). The inscription was identified already by the first editor, Jadwiga Kubińska, as a prayer from the Liturgy of the Presanctified..$^{38}$ The very last sentence of the inscription (line 20) contains the subscription of its author. Kubińska

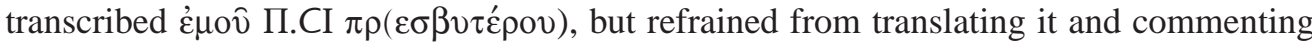
upon it. The reading was retained by Klaus Gamber in his edition; he only noted laconically that this is 'der Name des Schreibers'.$^{39}$

A closer inspection of the photograph (Fig. 9) allows correcting the reading. What Kubińska took to be a sigma seems to be rather a pi. Before it, I can see a triangular shape, which, given the two pis on its both sides, cannot be anything but an alpha. The subscription

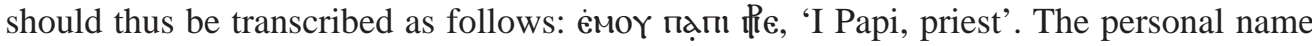
Papi derives most probably from the Old Nubian noun пап-, 'father'. It is quite well attested in Christian Nubia, occurring as both a simple name and an element of composite names (e.g. Papinga, Papinpesa, Papitime).

37 Michałowski, Jakobielski 1974: 200-204, no. 42.

${ }^{38}$ Kubińska 1976b: 18-25, 26, Fig. 18. For this particular service in Nubia, see, most recently: Łajtar, Zielińska 2016, where the present text is discussed at p. 441 (no. 1).

39 Gamber 1983: 28-30 with n. 53. 


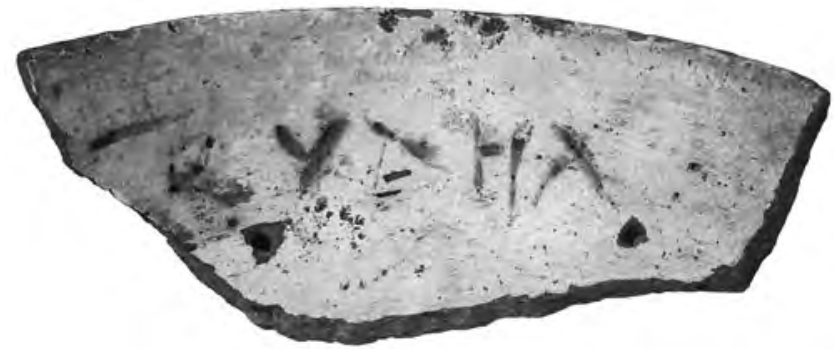

10. Inscription of $a b b a$ Chael (Phot. T. Górecki).

\section{INSCRIPTION OF ABBA CHAEL [DBMNT 2086]}

Among epigraphic finds unearthed by Polish archaeologists in Faras, there was a number of inscribed pottery fragments. They were partly published by Stefan Jakobielski ${ }^{40}$ and Jadwiga Kubińska. ${ }^{41}$ While the great majority of these inscriptions have an apotropaic function, invoking as they are various sacred names (Jesus Christ, Archangel Michael, and Four Living Creatures), there is at least one certain example of an owner inscription, a signature of a person who actually owned or used the vessel (inv. no. F 280/62-3; the object is stored in the Warsaw National Museum, inv. no. 234527).

The inscription consists of six characters, of which Kubińska was able to decipher only the last four: $\mathbf{x a H \lambda .}{ }^{42}$ Her reading is accurate, but her interpretation is not: while she is absolutely right that this is the abbreviated version of the name of Archangel Michael, she is mistaken in taking it as a reference to the archangel himself. That this is definitely not the case is proven by what can be read before it. Kubińska had troubles in identifying the letters. She wrote that this was probably une abréviation dont nous ne voyons que la dernière lettre, à savoir béta et une barre horizontale. ${ }^{43}$ Thanks to a photograph of the object kindly provided to me by the late Tomasz Górecki (Fig. 10), it is possible to identify the abbreviation as $\overline{\alpha B}$, standing for the title $\alpha \beta(\beta \alpha)$, habitual for members of the monastic order and bishops. The whole inscription should thus be transcribed $\overline{\alpha \mathrm{B}} \times \alpha \mathrm{\alpha} \lambda$, 'abba Chael', and there can be no doubt that a living person is at stake here, not a holy being.

Because of the archaeological context of the discovery, namely the environs of the Faras cathedral, one is tempted to identify our $a b b a$ Chael with one of the two bishops of Faras by that name: Chael I, whose episcopate fell in the 820s, or Chael II, officiating between 1097 and $1124 .{ }^{44}$ According to the ceramologist Katarzyna Danys (personal communication), the vessel bearing the inscription seems to be a yellow-slipped bowl made of alluvial clay and can perhaps be dated to the eleventh-twelfth century, which corresponds with the episcopate of Chael II. Note, however, that such an identification is

\footnotetext{
40 Jakobielski 1965: nos 61-74.

41 Kubińska 1974: nos 53-54, 99-100, 102-103, 105-106.

42 Kubińska 1974: no. 100, Fig. 89.

43 Kubińska 1974: 158.

44 Jakobielski 1972: 75 (Chael I) and 162-164 (Chael II).
} 
purely hypothetical, as the name Chael was one of the most popular male names in Christian Nubia, with forty-nine attestations, ten of which originating from Faras itself. Among them, there is also one abba Chael, priest, found in a list of priests of the cathedral of Faras recorded on a wall in the annex of the northern pastophorium. ${ }^{45} \mathrm{He}$ is, therefore, a possible candidate, too.

\section{Acknowledgments}

The article has been written within the framework of the project 'What's in a name?' A study on the onomastics of Christian Nubia financed by the National Science Centre of the Republic of Poland (no. 2015/17/D/HS3/00372). I would like to thank Adam Łajtar for his remarks on an earlier draft of the paper. The photographic documentation of the Polish mission to Faras used in this paper is stored at the Institute of Mediterranean and Oriental Cultures, Polish Academy of Sciences and was digitised within the framework of a scholarship granted by the Polish Centre of Mediterranean Archaeology of the University of Warsaw. I thank both institutions for allowing me to use this material.

\section{References}

Abbreviations of papyrological publications (O. Vind. Copt., P. KRU, P. Lond. Copt., SB) follow the standard established by the Checklist of Editions of Greek, Latin, Demotic, and Coptic Papyri, Ostraca, and Tablets, http://papyri.info/docs/checklist (accessed May 15, 2018)

Adams, W.Y. 1994: Kulubnarti I: The Architectural Remains, Lexington KY

Adams, W.Y. 2002: Meinarti III: The Late and Terminal Christian Phases, SARS Publication 9, BAR-IS 1072, London

Brunsch, W. 1991: Bemerkungen zu koptischen und griechischen Inschriften aus Kairo, Orientalia 60, 92-108

Brunsch, W. 1995: Koptische und griechische Inschriften in Kairo, EVO 18, 65-117

CIG IV: Curtius, E., Kirchhof, A., Corpus inscriptionum Graecarum IV, Berlin 1856-1859 DBMNT: www.dbmnt.uw.edu.pl (accessed May 15, 2018)

Donadoni, S. 1962: I graffiti della chiesa settentrionale, OrAnt 1, 93-97

Donadoni, S. 1975: Les graffiti de l'église de Sonqi Tino, [in:] Michałowski, K. (Ed.), Nubia. Récentes recherches. Actes du colloque nubiologique international au Musée National de Varsovie, 19-22 juin 1972, Warsaw, 31-39

Gamber, K. 1983: Zur Liturgie Nubiens. Die Kathedrale von Faras und ihre Wandmalereien, OstkStud 32, 21-35

Griffith, F.Ll. 1927: Oxford excavations in Nubia (XLIX-LV), AAALiv 14, 57-116

Jakobielski, S. 1965: Inscriptions chrétiennes, [in:] Michałowski, K. et al., Faras. Fouilles Polonaises 1961-1962, Faras II, Warsaw, 163-201

${ }^{45}$ Published in Jakobielski 1972: 198-199, and Kubińska 1974: no. 21 [DBMNT 1873]. For a new edition, see: Łajtar, Ochała 2018: no. 4. 
Jakobielski, S. 1972: A History of the Bishopric of Pachoras on the Basis of Coptic Inscriptions, Faras III, Warsaw

Jakobielski, S. 1974: Inscriptions, [in:] Michałowski, K., Jakobielski, S., Faras: Wall Paintings in the Collection of National Museum in Warsaw, Warsaw, 277-309

Junker, H. 1925: Die christliche Grabsteine Nubiens, ZÄS 60, 111-148

Kamel, I., Girgis, G.D. 1987: Catalogue général des antiquités du Musée copte, nos 1-253: Coptic Funerary Stelae, Cairo

Kubińska, J. 1974: Inscriptions grecques chrétiennes, Faras IV, Warsaw

Kubińska, J. 1976a: L’ange Litakskuel en Nubie, Le muséon 89, 451-455

Kubińska, J. 1976b: Prothesis de la Cathédrale de Faras: Documents et recherches, RAHA 9, $7-37$

Lefebvre, G. 1907: Recueil des inscriptions grecques-chrétiennes d’Égypte, Cairo

Łajtar, A., Ochała, G. 2015: Two wall inscriptions from the Faras cathedral with lists of people and goods, [in:] Łajtar, A., Ochała, G., Vliet, J. van der (Eds), Nubian Voices II: New Texts and Studies on Christian Nubian Culture, JJP-Suppl. XXVII, Warsaw, 73-102

Łajtar, A., Ochała, G. 2017: Two private prayers in wall inscriptions in the Faras cathedral, EtudTrav 30, 303-314

Łajtar, A., Ochała, G. 2018: Kimeliarches, 'treasurer': A so-far unidentified office in the Kingdom of Makuria (with notes on several other offices and titles), [in:] Bács, T.A., Bollók, Á., Vida, T. (Eds), Across the Mediterranean - Along the Nile. Studies in Egyptology, Nubiology and Late Antiquity Dedicated to László Török on the Occasion of His 75th Birthday, vol. 2, Budapest, 557-573

Łajtar, A., Twardecki, A. 2003: Catalogue des inscriptions grecques du Musée National de Varsovie, JJP-Suppl. II, Warsaw

Łajtar, A., Zielińska, D. 2016: The northern pastophorium of Nubian churches: ideology and function (on the basis of inscriptions and paintings), [in:] Łajtar, A., Obłuski, A., Zych, I. (Eds), Aegyptus et Nubia Christiana. The Włodzimierz Godlewski Jubilee Volume on the Occasion of His 70th Birthday, Warsaw, 435-457

Michałowski, K., Jakobielski, S. 1974: Faras: Wall Paintings in the Collection of National Museum in Warsaw, Warsaw

Mina, T. 1942: Inscriptions coptes et grecques de Nubie, Cairo

Monneret de Villard, U. 1933: Le iscrizioni del cimitero di Sakinya (Nubia), Cairo

Ochała, G. 2017: Nubica onomastica miscellanea II: Notes on and corrections to names found in inscriptions from Sakinya, BSAC 56, 127-138

Ochała, G. 2018: Nubica onomastica miscellanea III: Notes on and corrections to personal names found in Christian Nubian written sources, JJP XLVIII, 141-184

Ochała, G. forthcoming: Nubica onomastica miscellanea IV: Notes on and corrections to personal names found in Old Nubian documents from Qasr Ibrim, JJP XLIX

Pernigotti, S. 1975: Stele cristiane da Sakinya nel Museo di Torino, OrAnt 14, 21-55

Revillout, E. 1885: Les prières pour les morts dans l'épigraphie égyptienne, RevEg 4, 1-54 
Satzinger, H. 1992: Das altnubische Namenselement -кoү^ג: «Diener»?, [in:] Luft, U. (Ed.), The Intellectual Heritage of Egypt. Studies Presented to László Kákosy by Friends and Colleagues on the Occasion of His 60th Birthday, StudAeg 14, Budapest, 519-521

Tibiletti Bruno, M.G. 1964: Iscrizioni Nubiane, Pavia

Vliet, J. van der 1999: The Church of the Twelve Apostles: The earliest cathedral of Faras?, Orientalia 68/1, 84-97

Vliet, J. van der 2018: The Church of the Twelve Apostles: The earliest cathedral of Faras?, [in:] Vliet, J. van der, The Christian Epigraphy of Egypt and Nubia, Ed. Dekker, R., VCSS CS1070, Abingdon-New York, 327-339

Weißbrodt, W. 1905-1906: Ein aegyptischer christlicher Grabstein mit Inschrift aus der griechischen Liturgie im Königlichen Lyceum Hosianum zu Braunsberg und ähnliche Denkmäler in auswärtigen Museen. Teil I, Verzeichnis der Vorlesungen am Königlichen Lyceum Hosianum zu Braunsberg, Winter-Semester 1905/6, 3-26 
Tab. 1. Index of corrected names

\begin{tabular}{|c|c|c|c|c|}
\hline Name & New reading & Old reading & NOM I no. & DBMNT no. \\
\hline Anane - ghost-name & see Anani & & & \\
\hline Anani & ANANH & ANANE & 5 & $1830 \& 1831$ \\
\hline Chael & $\begin{array}{l}\overline{\mathrm{aB}} \times \mathrm{XH} \lambda \text { (name } \\
\text { of living person) }\end{array}$ & хан入 (name of Archangel) & 10 & 2086 \\
\hline $\begin{array}{l}\text { Iesou son of Mariami } \\
\text { - ghost-attestation }\end{array}$ & see Iesousinta(?) & & & \\
\hline Iesousinta(?) & 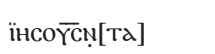 & 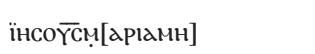 & 1 & 488 \\
\hline Inyitta & EIYTTd & $\operatorname{el\varphi [1]TTd~}$ & 6 & 1851 \\
\hline Papi & па̣ா & $\pi \mathrm{Cl}$ & 9 & 2112 \\
\hline Peti - ghost-attestation & see Petro (2) & & & \\
\hline Petro (1) & пєтро & сттеро & 7 & 1757 \\
\hline Petro (2) & пєтр(о) & пєтІ & 4 & 1666 \\
\hline Petro (3) & пєтро & not read & 8 & 1786 \\
\hline Petrou & $\begin{array}{l}\text { пєтроч } \\
\text { (as monogram) }\end{array}$ & пєтоү (as monogram) & 3 & 1673 \\
\hline Petu - ghost-name & see Petrou & & & \\
\hline Theophilos & eєọф̣ı & eecopla & 2 & 1592 \\
\hline Theoria - ghost-name & see Theophilos & & & \\
\hline
\end{tabular}




\section{ÉTUDES et TRAVAUX XXXII / 2019}

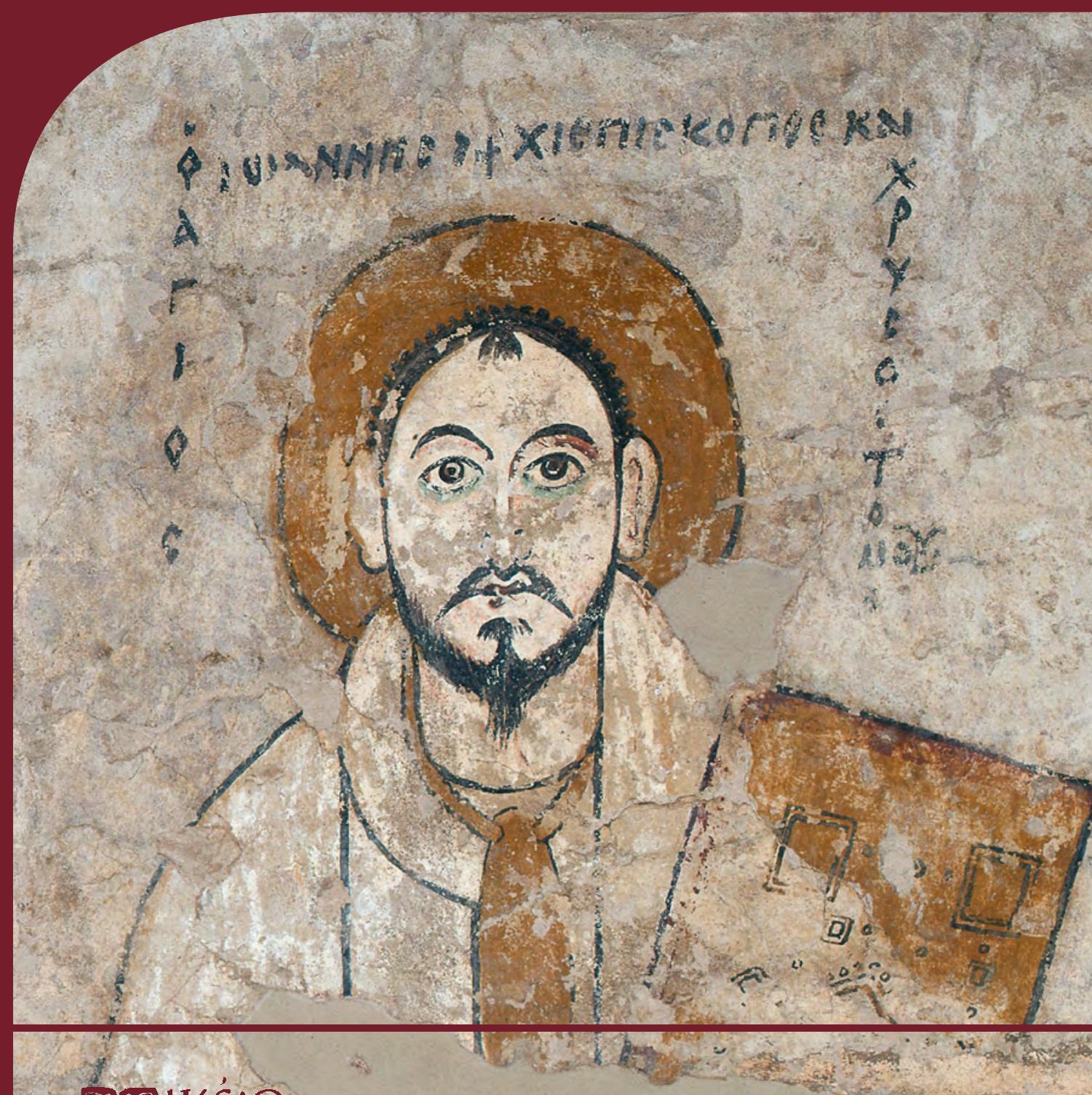

BOMIKSiO Institut des Cultures Méditerranéennes et Orientales ED2A PAN de l'Acácémie Polonaise des Sciences 


\title{
COMITÉ DE RÉDACTION SCIENTIFIQUE
}

Maciej Makowski - rédacteur en chef Jadwiga Iwaszczuk - rédacteur

Maciej G. Witkowski - rédacteur

Agnieszka Ryś - sécretaire de la rédaction

Bogdan Żurawski - rédacteur thématique du volume

CONSEIL SCIENTIFIQUE DU JOURNAL

M. Kobusiewicz (IAE PAN, Warszawa), E. Laskowska-Kusztal (IMOC PAS, Warszawa),

D. Michaelides (University of Cyprus, Nicosia),

J.Ch. Moretti (IRAA-MOM, Université de Lyon 2/CNRS),

D. Raue (Ägyptisches Museum der Universität Leipzig), P. Reynolds (ICREA, España),

D. Welsby (British Museum, London)

\section{COMITÉ SCIENTIFIQUE DE LECTURE}

D.E. Arnold (Wheaton College/The Field Museum, Chicago), H.D. Baker (University of Toronto),

P. Ballet (ArScAn-ESPRI, Université Paris Nanterre), Ch. Barber (Princeton University),

N. Beaux-Grimal (IFAO, Caire/Collège de France, Paris), A. Boud'hors (CNRS, IRHT, Paris),

J. Budka (Ludwig-Maximilians-Universität München), R. David (SFDAS),

A. Delattre (CPEG, Bruxelles), A. Dodson (University of Bristol),

E. Fogliadini (Facoltà Teologica dell'Italia Settentrionale, Milan),

V. Francigny (CNRS/CRES, Paris), L. Gabolde (CNRS), C. Gobeil (Egypt Exploration Society, London),

N. Hamdi (UCL, Louvain), J. den Heijer (CIOL/INCAL, Louvain-la-Neuve),

S. Ikram (American University in Cairo), Ch. Leitz (Universität Tübingen), S. Ortisi (Universität München),

E. Rova (Università Ca' Foscari Venezia), G. Ruffini (Fairfield University),

A. Sasson (San Diego Natural History Museum), H. Satzinger (Universität Wien),

S.M. Schellinger (The Ohio State University, Columbus), G. Schreiber (Eötvös Loránd University, Budapest),

E. Teeter (University of Chicago), S. Torallas-Tovar (University of Chicago),

Y. Tristant (Macquarie University, Sydney), V. Vaelske (independent researcher),

H. Vymazalová (Charles University, Prague), P. Weschenfelder (Universität Wien),

B. Williams (University of Chicago/PCMA UW, Warszawa),

K. Winther-Jacobsen (The Danish Institute at Athens), E. Zacharopoulou (University of Johannesburg),

P. Grotowski (UPJPII, Kraków), E. Papuci-Władyka, J. Śliwa (IA JU, Kraków), A. Ćwiek (IA AMU, Poznań),

K.O. Kuraszkiewicz, M. Pinker (FOS UW, Warszawa), Ł. Niesiołowski-Spanò (IH UW, Warszawa),

M. Gawlikowski, Mahmoud El-Tayeb (PCMA UW, Warszawa), S. Rzepka (IA UW, Warszawa)

\author{
RÉDACTION TECHNIQUE \\ Monika Wesołowska
}

REVUE DES TEXTES ANGLAIS

Jo Harper 
ÉTUDES et TRAVAUX

XXXII 
INSTYTUT KULTUR ŚRÓDZIEMNOMORSKICH I ORIENTALNYCH POLSKIEJ AKADEMII NAUK

\title{
STUDIA i PRACE
}

\author{
XXXII
}

GOMIKSIO

WARSZAWA

2019 
INSTITUT DES CULTURES MÉDITERRANÉENNES ET ORIENTALES DE L’ACADÉMIE POLONAISE DES SCIENCES

\section{ÉTUDES et TRAVAUX}

XXXII

VARSOVIE 2019 
Publication scientifique financée dans le cadre du programme du Ministre de la Science et de l’Éducation Supérieure

« Programme National de Développement de l’Humanistique » pour les années 2016-2021 (projet no $3 b H 150099$ 83)

\title{
TI NARODOWY PROGRAM ROZWOJU HUMANISTYKI
}

\author{
Copyright $(\mathbb{C}$ \\ Instytut Kultur Śródziemnomorskich i Orientalnych PAN \\ et les Auteurs \\ Warszawa 2019
}

\begin{abstract}
ISSN 2084-6762
(avant 2011 : 0079-3566)

e-ISSN 2449-9579

Version première en papier, imprimée en Pologne - 150 copies

Version électronique accessible sur

http://www.etudesettravaux.iksiopan.pl
\end{abstract}

Édition: Polskie Towarzystwo Historyczne et Wydawnictwo Neriton, Warszawa

Conception générale de couverture : J. Iwaszczuk

Photo de couverture : P. Ligier ; courtoisie du Musée National de Varsovie

(Saint Jean Chrysostome, peinture, cathédrale de Faras). 


\section{Table des matières}

Editorial: Quid novi ex Nubia (par Bogdan Żurawski) ............................................... 7

Bibliography of Professor Stefan Jakobielski ................................................................ 13

Aneta Cedro, Bogdan Żurawski

Living with the Past in Modern Sudanese Village. Traditional Pottery Production

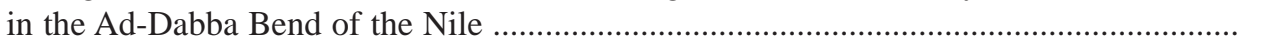

DAVID N. EDWARDS

A Possible Monastery and the 'Upper Maqs’ at Ukma-Akasha West? ............................ 53

Vincent W.J. van GeRven OeI

An Old Nubian Curse from the Faras Cathedral ........................................................ 81

Vincent W.J. van Gerven Oei, Adam Łajtar

Two Old Nubian Inscriptions from Akasha West ........................................................ 89

Vincent W.J. van Gerven Oei, Alexandros Tsakos

Rubrication Patterns in Two Old Nubian Manuscripts from Serra East .......................... 99

KAREL C. INNEMÉE

A Man in a Vessel, Once More .................................................................................. 111

KAREL C. INNEMÉE, Dobrochna ZielińSKA

Faces of Evil in Nubian Wall-Painting - An Overview ................................................ 121

ADAM ŁAJTAR

Epitaph of Merki Found in Hambukol ....................................................................... 145

MAGDALENA ŁAPTAŚ

Attributes, Vestments, Context and Inscription in the Identification of Nubian

Paintings: Proposing the 'Multi-Layer' Image Recognition Method ............................... 161

Grzegorz Ochala

Nubica Onomastica Miscellanea I: Notes on and Corrections to Personal Names

Found in Inscriptions from Faras 


\section{Robin SEIGNOBOS}

L'influence du Kitāb ahbār al-Nūba d'Ibn Sulaym al-Uswānī sur l'Histoire des églises et monastères d'Égypte d'Abū al-Makārim

JACQUES VAN DER VLIET

Exit Bishop Tamer - the Sequel. A New Edition of the Epitaph of Papsine alias Doulista (DBMNT 78) 